THE EFFECT OF HUMAN RESOURCES COMPETENCY, PARTICIPATION OF BUDGET

DEVELOPMENT, UTILIZATION OF INFORMATION TECHNOLOGY AND INTERNAL CONTROL SYSTEMS ON THE QUALITY OF FINANCIAL REPORT

\title{
PENGARUH KOMPETENSI SUMBER DAYA MANUSIA, PARTISIPASI PENYUSUNAN ANGGARAN, PEMANFAATAN TEKNOLOGI INFORMASI DAN SISTEM PENGENDALIAN INTERNAL TERHADAP KUALITAS LAPORAN KEUANGAN PEMDA KERINCI
}

\author{
Oleh: \\ Destipa Imelia $^{1)}$, Sri Rahayu ${ }^{2)}$, Wiralestari ${ }^{3)}$ \\ ${ }^{1)}$ Mahasiswai Magister Ilmu Akuntansi Pascasarjana Universitas Jambi Tahun 2020 \\ ${ }^{2 \& 3)}$ Fakultas Ekonomi dan Bisnis Universitas Jambi \\ Email: ${ }^{1)}$ i.destipa@yahoo.co.id ${ }^{2)}$ Srijambi@gmail.com, ${ }^{3)}$ wiralestari11@unja.ac.id
}

\begin{abstract}
This study aims to determine the effect of the influence of Human Resoursces Competence, Participation in Budgeting, Utilization of Information Technology and Internal Control Systems on the Quality of Financial Reports. The population taken in this study were all civil servants in 27 OPDs in Kerinci Regency. The sampling technique used was purposive sampling. As a sample, the researchers took 5 respondents from each OPD, with a total sample of 135 Civil Servants (PNS) as samples. The data analysis technique used is by using multiple regression. Hypothesis testing uses t-statistic test. The results of this study indicate that: (1) Together HR competence, budgeting participation, the use of information technology and government internal control systems have a significant effect on the quality of financial reports. (2) There is a significant influence between HR competencies on the quality of financial reports. (3) There is an influence on the level of budgetary participation on the quality of financial reports. (4) There is a significant positive effect between the use of information technology on the quality of financial reports, and (5) The Kerinci Regional Government's internal control system has a significant effect on the quality of regional financial reports.
\end{abstract}

Keywords: Human Resoursces Competence, Participation in Budgeting, Utilization of Information Technology, Internal Control Systems, Quality of Financial Reports

\begin{abstract}
ABSTRAK
Penelitian ini bertujuan untuk mengetahui pengaruh Pengaruh Kompetensi SDM, Partisipasi Penyusunan Anggaran, Pemanfaatan Teknologi Informasi dan Sistem pengendalian Internal Terhadap Kualitas Laporan Keuangan Pemda Kerinci. Populasi yang diambil dalam penelitian ini adalah seluruh Pegawai Negeri Sipil yang ada di 27 OPD Kabupaten kerinci, Teknik pengambilan sampel dengan menggunakan purposive sampling. Sebagai sampel peneliti mengambil 5 orang responden dari masing-masing OPD, dengan jumlah sampel sebanyak 135Pegawai Negeri Sipil (PNS) sebagai sampel.Teknik analisis data yang digunakan yaitu dengan menggunakan regresi berganda. Pengujian hipotesis menggunakan uji statistik t. Hasil penelitian ini menunjukkan bahwa: (1) Secara bersama-sama Kompetensi SDM, Partisipasi penyusunan anggaran, pemanfaatan teknologi informasi dan sistem pengendalian intern pemerintah berpengaruh signifikan terhadap kualitas laporan keuangan. (2) Hasil penelitian menunjukkan tidak adanya pengaruh yang signifikan antara kompetensi SDM dengan kualitas laporan keuangan.(3) Hasil pengukuran pengaruh tingkat partisipasi penyusunan anggaran terhadap kualitas laporan keuangan menunjukkan tidak adanya pengaruh yang signifikan (4) Hubungan membuktikan terdapat pengaruh positif yang signifikan antara pemanfaatan teknologi informasi dengan kualitas laporan keuangan. (5) Sistem pengendalian intern Pemda Kerinci tidak berpengaruh signifikan terhadap kualitas laporan keuangan daerah.
\end{abstract}

Kata Kunci: Kompetensi SDM, Partisipasi Penyusunan Anggaran, Pemanfaatan Teknologi Informasi, Sistem pengendalian Internal, Kualitas Laporan Keuangan 


\section{PENDAHULUAN}

\subsection{Latar Belakang}

Perkembangan kebutuhan peran Akuntansi pada sektor pelayanan publik di Indonesia saat ini yang semakin meningkat. Hal ini diperlukan dalam memenuhi tuntutan umum sebagai wujud pertanggungjawaban kepada masyarakat atas kinerja pemerintah untuk memberikan informasi yang lebih baik kepada publik, melalui laporan keuangan. Tujuan dari laporan keuangan adalah membantu para pengguna untuk mengevaluasi pelaksanaan kegiatan suatu entintas pelaporan dalam periode pelaporan sehingga memudahkan fungsi perencanaan, pengelolaan dan pengendalian atas seluruh asset, kewajiban dan ekuitas dana pemerintah untuk kepentingan masyarakat".(PP. No 71 Tahun 2010 ).

Kabupaten Kerinci sudah memperoleh Opini WTP (Wajar Tanpa Pengecualian) akan tetapi masih ada Reviu Laporan Keuangan Pemerintah Kabupaten Kerinci dari BPK salah satunya perbaikan laporan keuangan dibagian Aset. Hal ini perlu diperhatikan dan diketahui sedini mungkin sehingga Status Wajar Tanpa Pengecualian (WTP) yang diperoleh oleh Pemda Kerinci bisa dipertahankan untuk kedepannya.

Fakta dilapangan, proses pengendalian internal di kabupaten Kerinci sudah berjalan sesuai aturan, hal ini berdasarkan perolehan opini WTP selama 5 tahun kebelakangan. Meskipun demikian, tetap masih ada Reviu dari BPK, diantaranya:fungsi auditor internal Kabupaten Kerinci masih banyak bersifat korektif dan belum preventif, masih terdapat hasil pengawasan yang dibekukan. Hal tersebut menyebabkan peran aparat pengawasan internal pemerintah belum efektif, jika berlanjut akan berakibat merugikan pemerintah daerah,

Selain itu masih kurangnya SDM di Kabupaten Kerinci yang memiliki latar belakang akuntasi, hanya terdapat 1 orang SDM yang berlatar belakang pedidikan Akuntansi di bidang tersebut, sehingga berpengaruh pada Partisipasi SDM dalam penyusunan anggaran., serta faktor pemanfaatan TI yang kurang baik dalam pencatatan laporan keuangan.Beberapa hal diatas berkemungkinan mempengaruhi hasil laporan keuangan pemerintah yang diharapkan berkualitas dan mampu untuk dipertanggungjawabkan oleh pemerintah daerah Kerinci.

Berdasarkan hal diatas, menurut penulis, Hal ini juga harus diiringi dengan keterlibatan berbagai pihak dalam partisipasi penyusunan anggaran agar menjadi laporan keuangan yang akurat dan andal. Oleh karena itu peneliti termotivasi untuk melakukan penelitian dengan permasalahan tersebut menjadi topik yang menarik untuk diteliti, sehingga peneliti mengambil temayang berjudul "Pengaruh Kompetensi SDM, Partisipasi Penyusunan Anggaran, Pemanfaatan Teknologi Informasidan Sistem dan Pengendalian Internal Terhadap KualitasLaporan Keuangan PemdaKerinci

\subsection{Rumusan Masalah}

1. Apakah Kompetensi Sumber Daya Manusia, Partisipasi Penyusunan Anggaran Pemerintah, Pemanfaatan Teknologi Informasi dan Sistem Pengendalian Internal mempengaruhi Kualitas Laporan Keuangan Pemda Kerinci?

2. Apakah Kompetensi SDM mempengaruhi Kualitas Laporan Keuangan Pemda Kerinci?

3. Apakah Partisipasi Penyusunan Anggaran Pemerintah mempengaruhi Kualitas Laporan Keuangan Pemda Kerinci?

4. Apakah Sistem Pengendalian Internal mempengaruhi Kualitas Laporan Keuangan Pemda Kerinci?

5. Apakah Pemanfaatan Teknologi Informasi mempengaruhi Kualitas Laporan Keuangan Pemda Kerinci?

\subsection{Tujuan Penelitian}

1. Untuk menganalisis dan memperoleh bukti pengaruh Kompetensi Sumber Daya Manusia, Partisipasi Penyusunan Anggaran Pemerintah, Pemanfaatan Teknologi Informasi dan Sistem Pengendalian Internal terhadap Kualitas Laporan Keuangan Pemda Kerinci.

2. Untuk menganalisis dan memperoleh bukti pengaruh Kompetensi SDM terhadap Kualitas Laporan Keuangan Pemda Kerinci

3. Untuk menganalisis dan memperoleh bukti pengaruh Partisipasi Penyusunan Anggaran Pemerintah terhadap Kualitas Laporan Keuangan Pemda Kerinci

4. Untuk menganalisis dan memperoleh bukti pengaruh Sistem Pengendalian Internal terhadap Kualitas Laporan Keuangan Pemda Kerinci

5. Untuk menganalisis dan memperoleh bukti pengaruh Pemanfaatan Teknologi Informasi terhadap Kualitas Laporan Keuangan Pemda Kerinci

\section{KAJIAN PUSTAKA DAN PERUMUSAN HIPOTESIS}

\subsection{Kompetensi SDM}

Sumber daya manusia adalah semua orang yang terlibat dalam suatu pekerjaan di dalam sebuah lembaga/organisasi, dimana orang tersebut berfungsi sebagai aset yang dapat dihitung jumlahnya (Nawawi 2005: 37). Selanjutnya Ihsanti (2014) menjelaskan bahwa Kompetensi Sumber Daya Manusia merupakan kemampuan atau keahlian individu di dalam sebuah organisasi atau suatu sistem lembaga untuk mengimplementasikan skillnya dan melaksanakan fungsi serta kewenangannya dalam mencapai tujuannya secara efektif dan efisien. Kompetensi tersebut berupakemampuan untuk mencapai suatu kinerja, 
sehingga menghasilkan keluaran-keluaran (output) serta hasil-hasil (outcomes).

Soemardi (2010) menyebutkan Kompetensi dapat diartikan sebagai cerminan dari kemampuan atau keahlian seseorang pada suatu bidang tertentu seperti kemampuan prestasi, keahlian komunikasi verbal, pengetahuan teknis, kemampuan mengelola tekanan pekerjaan dan kemampuan membuat perencanaan dan keputusan. Semakin baik kualitas usmber saya manusia dimanfaatkan, semakin baik hasil kinerja yang diperoleh dan itu akan mengarah untuk pencapaian tunjan yang telah ditugaskan oleh organisasi itu sendiri. Untuk menilai kapasitas dan kompetensi sumber daya manusia dalam melaksanakan dungsi termasuk akuntansi, dapat dilihat dari tingkat tenggung jawab dan kompetensi sumber daya ini (Iskandar Muda, dkk. 2017).

Kualitas Sumber daya manusia yang baik mampu memberikan kontribusi yang optimal sehingga tujuan organisasi tercapai. Jadi, dapat disimpulkan bahwa Kompetensi SDM merupakan keahlian seseorang berdasarkan pengetahuan yang dimilikinya dibidang akuntansi, latar belakang pendidikan akuntansi, serta kemampuan dalam melaksanakan tugasnya di bidang yang berkaitan dengan akuntansi.

1. Pengetahuan, yaitu tahu dan memiliki informasidibidangakuntansi, memahami konsep atau hal-hal dibidang akuntansi, dapat mengaplikasikan pemahaman di bidang akuntasi, dapat menganalisis kemungkinan-kemungkinan yang ada dibidang akuntasi, serta dapat mengevalusi hal-hal berkaitan dibidang akuntasi.

2. Keterampilan, yaitu mampu menentukan cara menyelesaikan tugas, dapat menentukan prosedur terbaik dalam melaksanakan tugas, dapat meyelesaikan pekerjaan dengan baikdan terampil dalam menentukan ukuran kualitas terbaik suatu pekerjaan, mampu memprediksi hasil pekerjaan, serta terampil dalam mengelola emosional

3. Sikap/Perilaku, yaitu mampu mengendalikan diri, memiliki hubungan sosial, berkualitas dalam kualitas pekerjaan, serta memiliki kebiasaan kerja yang baik.

\subsection{Partisipasi Penyusunan Anggaran}

Partisipasi penyusunan anggaran merupakan kegiatan individu sebagai SDM mampu terlibat serta memiliki pengaruh dan mampu memberikan dampak dalam penentuan anggaran (Brownell,1982). Adapun indikator pengukuran Partisipasi Anggaran, adalah sebagai berikut:

a. Keterlibatan, berupa keaktifan SDM berpartisipasi dalam pekerjaan, dengan menunjukkan bahwa penyusunan anggaran sebagai hal yang utama, serta melihat pekerjaan penyusunan anggaran sebagai suatu yang penting bagi harga diri. b. Pengaruh, yaitu memiliki manfaat terhadap suatu pekerjaan dan memiliki efek/ dampak yang timbul atas penyusunan anggaran

c. Komitmen, yaitu adanya loyalitas, sikap terhadap tugastanggung jawab serta disiplin diri SDM dalam ikut terlibat penyusunan anggaran.

\subsection{Pemanfaatan Teknologi Informasi}

PP Nomor 56 tahun 2005 tentang sistem informasi keuangan aerah disebutkan pemerintah dan Pemda berkewajiban untuk mengembangkan dan memanfaatkan kemajuan teknologi informasi untuk meningkatkan kemampuan mengelola keuangan daerah dan menyalurkan informasi keuangan daerah kepada publik. Manfaat lain yang yang ditawarkan dalam pemanfaatan teknologi informasi adalah kecepatan dalam pemrosesan informasi. Oleh karena itu pemanfaatan teknologi informasi akan sangat membantu mempercepat proses pengolahan data transaksi dan penyajian laporan keuangan (Anggraeni, 2014).

\subsection{Sistem Pengendalian Internal}

Pengendalian Internal yang disampaikan oleh Konrath ( 2002:2015), mengutip Standar Profesional AICPA, Kontrol internal mendefenisikan sebagai berikut : Proses dilakukan oleh entitas dewan direksi, manajemen, dan personel lain yang dirancang untuk memberikan jaminan yang wajar mengenai pencapaian sasaran

Menurut Indra Bastian (2007: 7), Sistem Pengendalian Internal merupakan suatu proses yang dijalankan oleh eksekutif yang didesain untuk memberikan keyakinan yang memadai mengenai pencapaian keandalan laporan keuangan, kepatuhan terhadap hukum dan peraturan yang berlaku, serta efektivitas dan efisiensi operasi.

Menurut Peraturan Pemerintah Nomor 60 Tahun 2008 tentang Sistem Pengendalian Internal Pemerintah menyatakan bahwa:Sistem Pengendalian Internal adalah proses yang integral pada tindakan dan kegiatan yang dilakukan secara terus menerus oleh pimpinan dan seluruh pegawai untuk memberikan keyakinan memadai atas tercapainya tujuan organisasi melalui kegiatan yang efektif dan efisien, keandalan pelaporan keuangan, pengamanan aset negara, dan ketaatan terhadap peraturan perundang-undangan.

\subsection{Kualitas Laporan Keuangan}

PP No.71 tahun 2010 tentang Standar Akuntansi Pemerintah menyebutkan laporan keuangan adalah laporan terstruktur tentang posisi keuangan dan transaksi yang dilakukan oleh entitas pelapor.Haryanto (2007:17) menyebutkan Laporan Keuangan Pemerintah Daerah (LKPD) pada prinsipnya adalah hasil kombinasi atau konsolidasi dari laporan keuangan SKPD.Laporan keuangan pemerintah perlu memenuhi empat karakteristik berikut (PP 71 tahun 2010).

1) Relevan Laporan keuangan dikatakan relevan apabila informasi yang termuat didalamnya dapat 
mempengaruhi keputusan pengguna dengan membantu mereka mengevaluasi peristiwa masa lalu atau masa kini, memprediksi masa depan, dan menegaskan atau mengoreksi hasil evaluasi mereka. Selain itu informasi dapat dikatakan relevan jika disajikan tepat waktu dan lengkap.

2) Andal, Informasi yang andal memenuhi karakteristik: (a) Penyajian Jujur Informasi menggambarkan dengan jujur transaksi serta peristiwa lainnya yang seharusnya disajikan atau yang secara wajar dapat diharapkan untuk disajikan (b) Dapat Diverifikasi Informasi yang disajikan dalam laporan keuangan dapat diuji, dan apabila pengujian dilakukan lebih dari sekali oleh pihak yang berbeda, hasilnya tetap menunjukkan simpulan yang tidak berbeda jauh, serta netralitas informasi terjaga yaitu diarahkan pada kebutuhan umum dan tidak berpihak pada kebutuhan pihak tertentu.

3) Dapat dibandingkan, Informasi dalam laporan keuangan bebas dari pengertian yang menyesatkan dan kesalahan material, menyajikan setiap fakta secara jujur, serta dapat diverifikasi.

4) Dapat dipahami, yaitu Informasi yang disajikan dalam laporan keuangan dapat dipahami oleh pengguna dan dinyatakan dalam bentuk serta istilah yang disesuaikan dengan batas pemahaman para pengguna. Sehubungan dengan hal ini, pengguna diasumsikan memiliki pengetahuan yang memadai atas kegiatan dan lingkungan operasi entitas pelaporan, serta adanya kemauan pengguna untuk mempelajari informasi yang dimaksud.

\subsection{Model Penelitian}

Adapun model dalam penelitian ini adalah sebagai berikut:

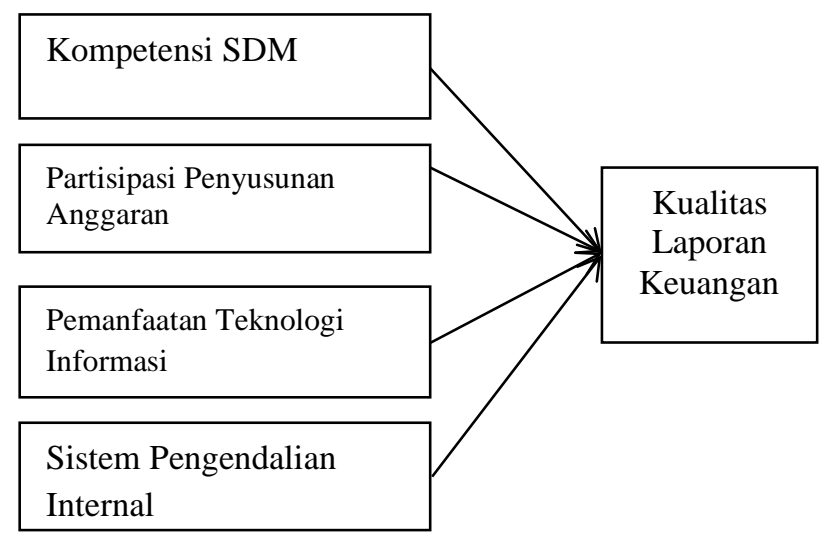

Sumber: diolah sendiri

\section{Gambar 1. Model Penelitian}

\subsection{Hipotesis}

H1: Terdapat pengaruh antara Kompetensi Sumber Daya Manusia, Partisipasi Penyusuna Anggaran Pemerintah, Pemanfaatan Teknologi Informasi dan Sistem Pengendalian Internal terhadap
Kualitas Laporan Keuangan Pemda Kerinci.

$\mathrm{H}_{2}$ : Terdapat pengaruh Kompetensi Sumber Daya Manusia terhadap Kualitas Laporan Keuangan Pemda Kerinci.

$\mathrm{H}_{3}$ : Terdapat pengaruh Partisipasi Penyusunan Anggaran Pemerintah terhadap Kualitas Laporan Keuangan Pemda Kerinci.

$\mathrm{H}_{4}$ : Terdapat pengaruh Sistem Pemanfaatan Teknologi Informasi terhadap Kualitas Laporan Keuangan Pemda Kerinci.

$\mathrm{H}_{5}$ : Terdapat pengaruh Sistem Pengendalian Internal terhadap Kualitas Laporan Keuangan Pemda Kerinci.

\section{METODE PENELITIAN}

\subsection{Jenis dan Sumber Data}

Penelitian ini merupakan penelitian Deskriptif dengan motode survei. Survei merupakan teknisk riset yang informasinya dikumpulkan melalui penggunaan kuesioner. Menurut Sugiyono (2018), penelitian deskriptif merupakan penelitian yang dilakukan untuk mengetahui nilai variabel mandiri, baik satu variabel atau lebih (independen) tanpa membuat perbandingan atau hubungan dengan variabel lain.Penggunaan penelitian deskriptif ini dimaksudkan untuk mencari fakta dengan interprestasi yang tepat dan tujuannya adalah untuk mencari gambaran yang sistematis dan akurat mengenai faktor-faktor, sifat-sifat serta hubungan antara fenomena yang diselidiki.

Penelitian Survei adalah penelitian kuantitatif yang digunakan untuk mendapatkan data yang terjadi pada masa lampau atau saat ini, tentang keyakinan, pendapat, karakteristik, perilaku, hubungan variabel dan untuk menguji beberapa hipotesis tentang variabel sosiologis dan psikologis dari sampel yang diambil dari populasi tertentu, teknik pengumpulan data dengan pengamatan (wawancara atau kuesioner).(Sugiyono 2018)

\subsection{Metode Pengumpulan Data.}

Untuk pengumpulan informasi dari data yang diperlukan, pengumpulan data yang digunakan sebagai berikut :

\section{Penelitian Kepustakaan (Library Research)}

Penelitian ini dilakukan dengan cara mempelajari literatur, jurnal, laporan dan dokumen yang relevan dengan masalah yang diteliti.

\section{Penelitian Lapangan (Field Reseach)}

Penelitian dilakukan dengan membuat daftar pertanyaan (quesitioner), yaitu metode pengumpulan data dengan membuat daftar pertanyaan dalam bentuk angket yang ditunjukan kepada para pegawai atau responden di objek penelitian. 


\subsection{Populasi dan Sampel}

Populasi dalam penelitian ini adalah selluruh Pegawai Negeri Sipil yang ada di 27 OPD Kabupaten kerinci, Teknik pengambilan sampel dengan menggunakan purposive sampling, dengan kriteria sebagai berikut:

1. PNS yang melaksanakan urusan wajib secara menyeluruh dalam pengelolaanPemda Kerinci

2. Terlibat dan berkaitan langsung secara teknis dengan pengelolaan keuangan, pengevaluasian keuangan dan penyusunan laporan keuangan di instansi Pemda Kerinci.

3. Terdiri dari Kadis, Sekdis, Kabid, Kasidan Bendahara Pengeluaran Pengelola Keuangan dari masing-masing OPD

Sampel yang didapat setelah memilih berdasarkan kriteria diatas, peneliti mengambil 5 orang responden dari masing-masing OPD, dengan jumlah sampel sebanyak 135Pegawai Negeri Sipil (PNS) sebagai sampel

\subsection{Operasional Variabel}

Variabel-variabel dalam penelitian ini terdiri dari 4 variabel independen yaitu Kompetensi SDM, Partisipasi Penyusunan Anggaran, Pemanfaatan Teknologi Informasi dan Sistem Pengendalian Internal serta 1 variabel dependen yaitu Kualitas Laporan Keuangan Pemda Kerinci.

Tabel 1. Operasional variabel

\begin{tabular}{|c|c|c|}
\hline \multirow{2}{*}{$\begin{array}{l}\text { Definisi/ } \\
\text { Variabel }\end{array}$} & \multicolumn{2}{|l|}{ Pengukuran } \\
\hline & Indikator & Skala \\
\hline $\begin{array}{l}\text { Kualitas } \\
\text { Laporan } \\
\text { Keuagan }(\mathrm{Y})\end{array}$ & $\begin{array}{ll}\text { 1. } & \text { Relevan } \\
\text { 2. Andal } \\
\text { 3. } \\
\text { 4. } \text { Dapat dibandingkan dipahami }\end{array}$ & Ordinal \\
\hline $\begin{array}{l}\text { Kompetensi } \\
\text { SDM(X1) }\end{array}$ & $\begin{array}{ll}\text { 1. } & \text { Pengetahuan } \\
\text { 2. } & \text { Keterampilan } \\
\text { 3. } & \text { Sikap/Perilaku } \\
\end{array}$ & Ordinal \\
\hline $\begin{array}{l}\text { Partisipasi } \\
\text { Penyusunan } \\
\text { Anggaran } \\
\text { (X2) }\end{array}$ & $\begin{array}{ll}\text { 1. } & \text { Keterlibatan } \\
\text { 2. } & \text { Pengaruh } \\
\text { 3. } & \text { Komitmen }\end{array}$ & Ordinal \\
\hline $\begin{array}{l}\text { Pemanfaatan } \\
\text { Teknologi } \\
\text { Informasi(X3) }\end{array}$ & $\begin{array}{l}\text { 1. intensitas pemanfaatan } \\
\text { 2. frekuensi pemanfaatan } \\
\text { 3. jumlah aplikasi atau } \\
\text { perangkat lunak yang } \\
\text { digunakan }\end{array}$ & Ordinal \\
\hline $\begin{array}{l}\text { Sistem } \\
\text { Pengendalian } \\
\text { Internal (X4) }\end{array}$ & $\begin{array}{ll}\text { 1. } & \text { Lingkungan } \\
\text { 2engendalian } \\
\text { 2. } & \text { Pengendalian resiko } \\
\text { 3. } & \text { Aktivitas pengendalian } \\
\text { 4. } & \text { Informasidan } \\
\text { komunikasi } \\
\text { 5. } & \text { monitoring }\end{array}$ & Ordinal \\
\hline
\end{tabular}

Sumber: Hasil pengolahan data dengan SPSS

\subsection{Uji Kualitas Data}

\section{Uji Validitas}

Uji Validitas data instrument pada penelitian ini dilakukan dengan membandingkan nilai Correlated Item-Total Correkation pada setiap butir pertanyaan dengan nilai $r$ tabel produk moment. Jika Correlated Item-Total Correkation $\mathrm{r}$ hitung $>$ nilai $\mathrm{r}$ tabel, maka butir pertanyaan pada setiap variabel penelitian dinyatakan valid (Ghozali, 2018). Untuk melakukan pengujian validitas instrument dilakukan dengan menggunakan software statiscal package for social science (SPSS) 21.

\section{Uji Reabilitas}

Uji Reabilitas merupakan alat ukur untuk kuesioner yang merupakan indikator dari variabel, suatu kuesioner dikatakan handal jika jawabannya dari responden terhadap pertanyaan adalah konsisten atau stabil dari waktu ke waktu. Jawaban responden terhadap pertanyaan dikatakan handal jika masingmasing pertanyaan dijawab secara konsisten. Ghozali (2018) menyatakan bahwa pengukuran reliabilitas dapat dilakukan dengan 2 (dua) cara yaitu :

a. Repeated Measure atau pengukuran ulang dilakukan dengan cara memberikan kuesioner (pertanyaan yang sama pada waktu yang berbeda kemudian dilihat apakah responden tetap konsisten dengan jawaban.

b. One shot atau pengukuran sekali saja dilakukan dengan cara hanya sekali saja kuesioner diberikan kepada responden dan kemudian hasilnya dibandingkan pertanyaan lain atau mengukur korelasi antar jawaban pertanyaan.Sementara, hasil uji reliabilitas dengan melihat nilai cronbach alpha, dimana seluruh variabel memiliki nilai cronbach alpha yanglebih besar dari 0,6 menunjukkan bahwa seluruh instrumentvariabel penelitian dapat dinyatakan reliabel.Untuk melakukan pengujian reliabilitas kuesioner dilakukan dengan menggunakan software statistical packagefor social science (SPSS).

\subsection{Deskriptif statistic}

Teknik analisis deskriptif statistic dilakukan menggunakan SPSS for windows.Adapun langkahlangkah yang dilakukan adalah:

1. Menentukan nilai skor jawaban dari item pernyataan, untuk item rentang skor 5-1

2. Menghitung statistik deskriptif dengan bantuan SPSS for windows untuk menentukan nilai minimal, maksimal, mean dan standar deviasi

3. Dari hasil kuantitatif di atas diubah dengan analisis deskriptif yang bersifat kualitatif.

4. Menentukan kategorisasi untuk mempermudah dalam menganalisis. 
Tabel 2. Rumus Kategorisasi

\begin{tabular}{|l|l|}
\hline Rumus & Kategorisasi \\
\hline $\mathrm{X}<\mathrm{M}-1 . \mathrm{SD}$ & RENDAH \\
\hline $\mathrm{M}-1 . \mathrm{SD} \leq \mathrm{X}<\mathrm{M}+1 . \mathrm{SD}$ & SEDANG \\
\hline $\mathrm{M}+1 . \mathrm{SD} \leq \mathrm{X}$ & TINGGI \\
\hline
\end{tabular}

Ket: $\mathrm{M}=$ rata-rata

SD $\quad=$ Standar Deviasi

Sumber: Azwar (2012)

\subsection{Uji asumsi klasik}

Pengujian asumsi klasik yang digunakan adalah uji multikolinearitas, uji heteroskedastisitas, dan uji normalitas. Adapun kriteria pengambilan keputusan terhadap masing-masing uji asumsi klasik tersebut sebagai berikut:

1. Pendeteksian normalitas dilakukan dengan uji kolmogorovsmirnov dengan kriteria apabila nilai signifikan uji kolmogorovsmirnov lebih besar dari 0,05 dapat dinyatakan bahwa residual data berdistribusi normal.

2. Pengujian terjadinya multikoloniearitas dengan melihat nilai tolerance $<0,10$ atau sama dengan nilai VIF > 10 (Ghozali,2013:106).

3. Pendeteksian ada atau tidaknya heteroskedastisitas dilakukan dengan uji glejser dengan membandingkan nilai signifikan masing-masing variabel lebih besar dari derajat kepercayaan yang telah ditentukan (5\%).

\subsection{Analisis Regresi Linear Berganda}

Metode analisis yang digunakan dalam penelitian ini adalah Regresi Linear Berganda. Menurut Junaidi (2015) metode ini digunakan untuk menguji pengaruh antar variabel dependent dan variabel independent. Untuk mengidentifikasi faktor yang mempengaruhi kualitas laporan keuangan digunakan persamaan regresi linier berganda (multiple Linear Regression). Variabel dependent pada penelitian ini adalah Kualitas Laporan Keuangan, sedangkan variabel independent adalah Kompetensi SDM, Partisipasi Penyusunan Anggaran, Sistem Pengendalian Internal dan Pemanfaatan Teknologi Informasi. Adapun bentuk matematis analisis regresi linier berganda sebagai berikut :

$$
\mathrm{Y}=\alpha+\beta_{1} X_{1}+\beta_{2} X_{2}+\beta_{3} X_{3}+\beta_{4} X_{4+} \mathrm{e}
$$

\section{Keterangan:}

$\begin{array}{ccl}\mathrm{Y} & : \text { Kualitas Laporan Keuangan Pemerintah Daerah } \\ \mathrm{A} & : \text { Nilai konstanta } \\ \mathrm{B}_{1 \ldots 4} & : \text { Koefisien regresi } \\ \mathrm{X}_{1} & : \text { Kompetensi Sumber Daya Manusia } \\ \mathrm{X}_{2} & : \text { Partisipasi Penyusunan Anggaran Pemerintah } \\ \mathrm{X}_{3} & : \text { Sistem Pengendalian Internal } \\ \mathrm{X}_{4} & : \text { Pemanfaatan Teknologi Informasi } \\ \mathrm{E} & : \text { Eror }\end{array}$

Selanjutnya dalam menganalisa dan pembahasan hasil kuantitatif menggunakan Dekriptif Kuantitatif, yaitu suatu cara menganalisa data hasil melalui kuesioner dituangkan dalam bentuk tabel dan di tabulasi dari data kualitatif menjadi kuantitatif dengan perhitungan yang dibantu menggunakan skala likert. Menurut Sugiyono (2018) menyatakan skala likert digunakan untuk mengukur ketegasan, kejelasan dan konsistensi terhadap fenomena sosial.

\section{HASIL DAN PEMBAHASAN}

\subsection{Uji Validitas dan Reliabilitas}

\subsubsection{Uji Validitas}

Dari hasil uji validitasdapat diketahui mana item yang valid atau tidak. Item yang valid layak untuk dilanjutkan ke penelitian. Berdasarkan hal tersebut penulis mengambil batas validitas terbawah yaitu nilai Corrected Item-Total Correlation $>0,17$. Pada variabel kompetensi SDM dari 21 item diperoleh sebanyak 18 item yang valid, karena $R$ hitung lebih besar dari 0,17 sedangkan tidak valid 4 item. Item yang tidak valid dibuang karena tidak selaras dengan butir yang lain.(Sugiyono, 2018:199).

Pada variabel partisipasi penyusunan anggaran, pemanfaatan TI dinyatakan valid secara keseluruhan karena $R$ hitung lebih besar dari 0,17. Selanjutnya Pada instrument variabel pengendalian internal sebanyak 17 item, dinyatakan valid keseluruhan karena $R$ hitung lebih besar dari 0,17 dan 7 tidak valid. Item yang tidak valid dibuang karena tidak selaras dengan butir yang lain.(Sugiyono, 2018:199). Pada instrumen skala kualitas laporan keuangan sebanyak 9 item dinyatakan valid secara keseluruhan karena $R$ hitung lebih besar dari 0,17 .

\subsubsection{Uji Reliabilitas}

Uji reliabilitas dilakukan mengunakan program SPSS for windows dengan menggunakan teknik alphacronbach.Pengujian reliabilitas kuesioner dalam penelitian ini menggunakan one shot atau pengukuran sekali saja dan untuk penguji reliabilitasnya digunakan uji statistik cronbach alpha. Variabel dikatakan reliable jika memberikan nilai Conbach Alpha> $r$ table. (Ghozali, 2018 : 45).

Tabel 3. Hasil Uji Reliabilitas Instrumen

\begin{tabular}{|c|l|r|c|c|}
\hline NO & \multicolumn{1}{|c|}{ Variabel } & $\begin{array}{c}\text { Cronbach's } \\
\text { Alpha }\end{array}$ & R table & Kesimpulan \\
\hline 1 & Kompetensi SDM & 0,449 & 0,176 & Reliable \\
\hline 2 & $\begin{array}{l}\text { Partisipasi } \\
\text { Penyusunan } \\
\text { Anggran }\end{array}$ & 0,909 & 0,176 & Reliable \\
\hline 3 & Penggunaan TI & 0,893 & 0,176 & Reliable \\
\hline 4 & $\begin{array}{l}\text { Pengendalian } \\
\text { Internal }\end{array}$ & 0,519 & 0,176 & Reliable \\
\hline 5 & $\begin{array}{l}\text { Kualitas Laporan } \\
\text { Keuangan }\end{array}$ & 0,781 & 0,176 & Reliable \\
\hline
\end{tabular}

Sumber: SPSS

Dari hasil uji reliabilitas di atas, diketahui nilai Cronbach Alpha diperoleh lebih besar dari 0,176 maka reliabilitasnya adalah sangat baik, sehingga dapat digunakan sebagai alat ukur. 
Pengaruh Kompetensi Sumber Daya Manusia, Partisipasi Penyusunan Anggaran, Pemanfaatan Teknologi Informasi dan Sistem Pengendalian Internal Terhadap Kualitas Laporan Keuangan Pemda Kerinci (Destipa Imelia, Sri Rahayu dan Wiralestari)

\subsection{Statistik Deskriptif}

Data dalam penelitian ini merupakan data primer yang berasal dari kuesioner yang disebar keseluruh 27 OPD di Kabupaten Kerinci.Kuesioner didistribusikan kepada 27 OPD yang menjadi sampel penelitian. Setiap OPD dipilih lima orang responden untuk mengisi kuesioner penelitian. Pendistribusian kuesioner dalam penelitian ini dilakukan melalui google form.Kuesioner diberikan kepada Kepala OPD, Sekdis, Bendahara, Kabid dan Kasi sebagai pihak yang terlibat langsung dalam kegiatan pengelolaan dan pertanggungjawaban keuangan. Proses pendistribusian hingga pengumpulan data dilakukan selama dua minggu atau sepuluh hari kerja pada tanggal 14 September 2020 sampai dengan tanggal 4 Oktober 2020.

Berdasarkan jumlah, kuesioner yang didistribusikan adalah 135 kuesioner atau 27 OPD yang menjadi sampel penelitian. Terdapat beberapa OPD yang tidak mengembalikan kuesioner. Dengan demikian jumlah kuesioner yang kembali sebanyak 92 kuesioner atau sebesar $68.15 \%$ kuesioner yang kembali.Secara jelasnya mengenai deskriptif data penelitian dapat dilihat pada tabel 4

Tabel 4. Deskripsi Pengembalian Sampel

\begin{tabular}{|l|l|l|}
\hline Keterangan & $\begin{array}{l}\text { Jumlah } \\
\text { Sampel }\end{array}$ & $\begin{array}{l}\text { Persent } \\
\text { ase (\%) }\end{array}$ \\
\hline $\begin{array}{l}\text { Kuisioner yang } \\
\text { didistribusikan }\end{array}$ & 135 Kuisioner & $100 \%$ \\
\hline $\begin{array}{l}\text { Kuisioner yang tidak } \\
\text { kembali }\end{array}$ & 43 Kuisioner & $25.6 \%$ \\
\hline $\begin{array}{l}\text { Kuisioner yang } \\
\text { digunakan } \\
\text { penelitian }\end{array}$ dalam & 93 Kuisioner & $74.4 \%$ \\
\hline
\end{tabular}

Sumber : Data diolah (2020)

Berdasarkan hasil uji kuesioner diperoleh gambaran mengenai variabel penelitian yang menunjukkan nilai maksimum, nilai minimum, nilai rata-rata dan standar deviasi dari setiap variabel yang dapat dilihat pada Tabel 5

\section{Tabel 5. Statistik Deskriptif}

\begin{tabular}{|l|c|c|c|c|c|c|}
\hline & $\mathrm{N}$ & $\begin{array}{c}\text { Mini } \\
\text { mum }\end{array}$ & $\begin{array}{l}\text { Maxi } \\
\text { mum }\end{array}$ & Mean & Stdev. & Kategori \\
\hline $\begin{array}{l}\text { Kompetensi } \\
\text { SDM }\end{array}$ & 93 & 1 & 5 & 3,86 & 0,78 & Sedang \\
\hline $\begin{array}{l}\text { Partisipasai } \\
\text { Penyusunan } \\
\text { Anggaran }\end{array}$ & 93 & 1 & 5 & 3,90 & 0,73 & Sedang \\
\hline $\begin{array}{l}\text { Penggunaan } \\
\text { TI }\end{array}$ & 93 & 1 & 5 & 3,97 & 0,67 & Sedang \\
\hline $\begin{array}{l}\text { Sistem } \\
\begin{array}{l}\text { Pengendalian } \\
\text { Internal }\end{array}\end{array}$ & 93 & 1 & 5 & 3,91 & 0,74 & Sedang \\
\hline $\begin{array}{l}\text { Kualitas } \\
\text { Lapkeu }\end{array}$ & 93 & 1 & 5 & 3,92 & 0,72 & Sedang \\
\hline $\begin{array}{l}\text { Valid N } \\
\text { (Listwise) }\end{array}$ & 93 & & & & & \\
\hline
\end{tabular}

Sumber :Output SPSS (2020)
Pada variabel Kompetensi SDM diketahui total skor terendah dari jawaban responden adalah 1 dan skor tertinggi dari jawaban responden adalah 5 sehingga rata-rata (mean) jumlah skor jawaban Kompetensi SDM adalah 3,86 dengan kategori sedang. Hal ini menunjukan bahwa rata-rata responden memiliki kompetensi, yang cukup dalam memahami, mengerti dan melaksanakan tugasnya sebagai SDM dalam pengelolaan keuangan di OPD masing-masing.

Pada variabel partisipasi penyususnan anggaran diketahui total skor terendah dari jawaban responden adalah 1 dan skor tertinggi dari jawaban responden adalah 5 sehingga rata-rata (mean) jumlah skor jawaban partisipasi penyususnan anggaran adalah 3,90 dengan kategori sedang. Hal ini menunjukan bahwa rata-rata responden belum dapat terlibat secara maksimal, atas pengelolaan keuangan di OPD masing-masing.

Pada variabel Penggunaan TI diketahui total skor terendah dari jawaban responden adalah 1 dan skor tertinggi dari jawaban responden adalah 5 sehingga rata-rata (mean) jumlah skor jawaban pemanfaatan TI adalah 3,97 dengan kategori sedang. Hal ini menunjukkan bahwa rata-rata responden belum sepenuhnya mampu memanfaatkan teknologi informasi sesuai dengan standar dalam pengelolan keuangan OPD masing-masing.

Pada variabel system pengendalian internal diketahui skor terendah dari jawaban responden yaitu 1 dan skor tertinggi dari jawaban responden adalah 5 sehingga rata-rata (mean) total jumlah skor jawaban responden atas system pengendalian internal adalah 3,91 dengan kategori sedang. Hal ini menunjukkan bahwa rata-rata pelaksanaan system pengendalian internal pada masing-masing OPD sudah terlaksana cukup baik.

Untuk variabel kualitas laporan keuangan memiliki skor terendah dari jawaban responden yaitu 1 dan skor tertinggi dari jawaban responden adalah 5 sehingga rata-rata (mean) jumlah skor jawaban kualitas laporan keuangan adalah 3,92 dengan kategori sedang. Hal ini berarti bahwa masih ada responden yang belum sepenuhnya memahami bagaimana kualitas laporan keuangan yang sesuai standar yaitu relevan, andal, dapat dibandingkan dan dapat dipahami.

\subsection{Uji Asumsi Klasik}

\subsubsection{Uji Normalitas}

Tabel 6. Uji Normalitas

One-Sample Kolmogorov-Smirnov Test

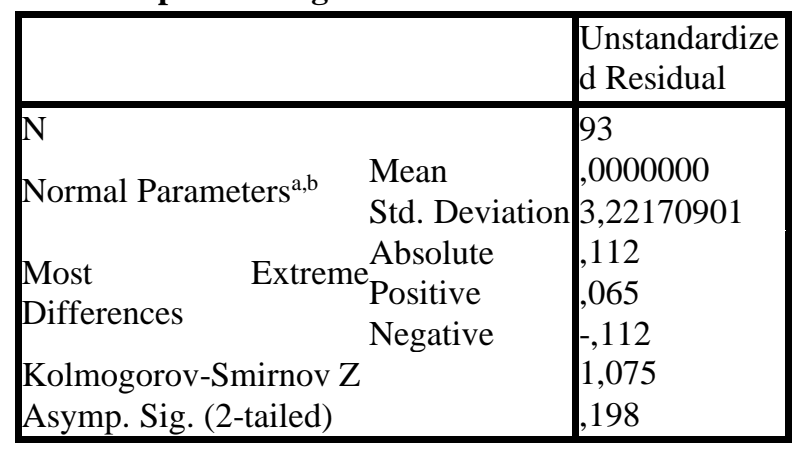


a. Test distribution is Normal.

b. Calculated from data.

Sumber :Output SPSS (2020)

Berdasarkan Tabel di atas dapat diketahui nilai asymp.sig sebesar 0,198> 0,05 sehingga dapat disimpulkan bahwa data berdistribusi normal

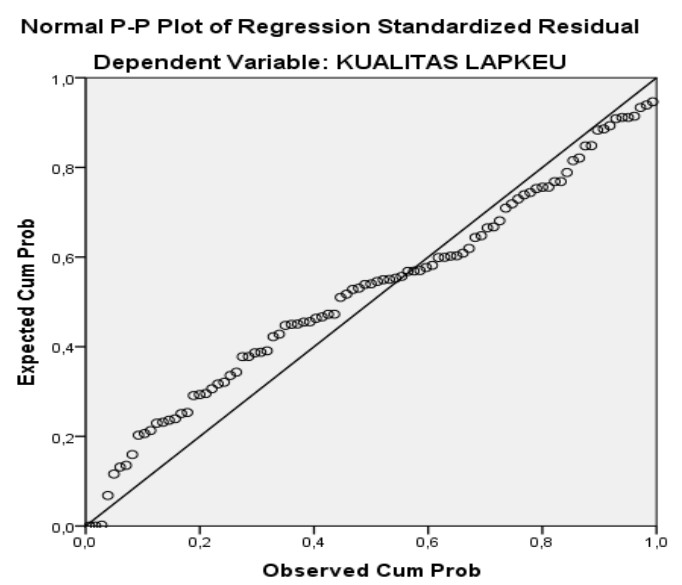

Sumber :Output SPSS (2020)

\section{Gambar 2. Uji Normalitas}

Gambar 2 di atas diketahui data mengikuti arah garis diagonal dan tidak melebar atau menyebar disekitar garis diagonal maka data berdistribusi normal.

\subsubsection{Uji Multikolinearitas}

Uji multikolinieritas bertujuan untuk melihat kemiripan antara variabel independen yang satu dengan variabel independen yang lain dalam suatu model, untuk mengetahuinya digunakan Variance Inflation Factor (VIF) pada model regresi. dengan kriteriakriteria jika VIF $>10$, maka variabel tersebut mempunyai persoalan multikolinieritas dengan variabel bebas lainnya, sedangkan jiak $\mathrm{VIF}<10$ maka variabel bebas tidak mempunyai persoalan multikolinieritas.

\section{Tabel 7. Uji Multikolinearitas}

\section{Sumber :Output SPSS (2020)}

Berdasarkan tabel 7 diatas dapat diketahui bahwa semua varibel independen memiliki nilai tolerance value $>0,10$ atau nilai VIF $<10$ sehingga dapat dikatakan tidak terjadi multikolinieritas antar variabel independen.

\subsubsection{Uji Heteroskedastisitas}

Uji heteroskedastisitas bertujuan untuk menguji apakah sebuah model regresi terjadi ketidaksamaan varians dari residual atas satu pengamatan ke pengamatan yang lain. Jika varians dari residual suatu pengamatan ke pengamatan lain tetap, maka disebut homoskedatisitas dan jika berbeda disebut heteroskedastisitas. Dalam penelitian ini, untuk mendeteksi ada tidaknya gejala heteroskedastisitas adalah menggunakan Uji Gletser.Menurut Imam Ghozali (2013:142) uji Glejser dapat diuji dengan meregres nilai absolut residual terhadap variabel independen. Dengan menggunakan dasar pengambilan keputusan sebagai berikut: (a) Jika nilai Signifikansi variabel independent $<0,05$ : terjadi heteroskedastisitas. (b) Jika nilai Signifikansi variabel independent> 0,05: tidak terjadi heteroskedastisitas.

Tabel 8. Uji Heteroskedasitas

\begin{tabular}{|ll|l|}
\hline \multicolumn{1}{|l|}{ Model } & Sig. \\
\hline 1 & & 0,422 \\
& (Constant) & \\
& X1 & 0,999 \\
& X2 & 0,256 \\
& X3 & 0,694 \\
& X4 & 0,06 \\
\hline
\end{tabular}

a. Dependent Variable: ABS_RES2

Sumber : Output SPSS (2020)

Dari tabel di atas diperoleh nilai signifikansi X1, $\mathrm{X} 2$,X3, dan X4 lebih besar dari 0,05 maka asumsi heterokedasitas terpenuhi, yaitu tidak terdapat heterokedasitas pada variabel diatas

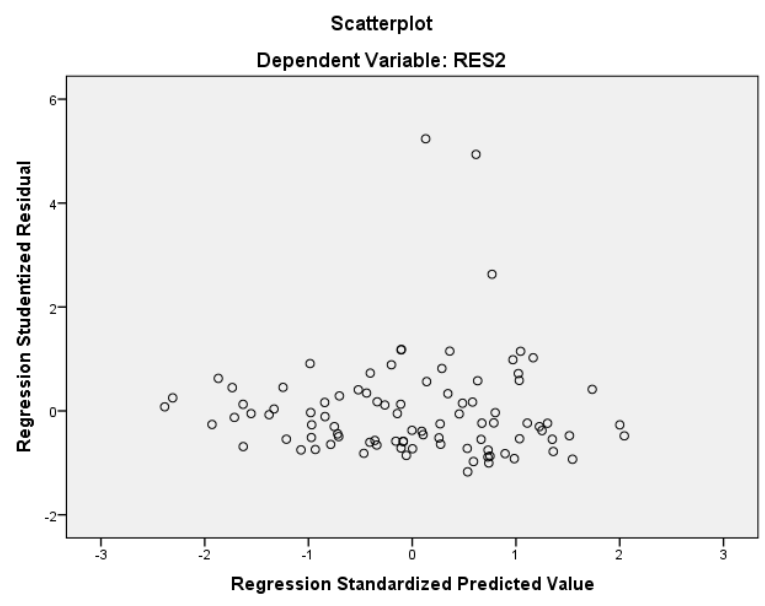

Sumber : Output SPSS (2020)

\begin{tabular}{|ll|l|l|}
\hline Model & \multicolumn{2}{|c|}{ Collinearity Statistics } \\
\cline { 2 - 4 } & (Constant) & & \\
\hline \multirow{2}{*}{1} & Tolerance & VIF \\
KOMPETENSI SDM &, 595 & 1,680 \\
PARTISIPASAI &, 305 & 3,279 \\
PENYUSUNAN & & \\
ANGGARAN & & \\
& PENGGUNAAN TI &, 199 & 5,014 \\
& SISTEM & 326 & 3,068 \\
PENGENDALIAN & & \\
INTERNAL & & \\
\hline
\end{tabular}

\section{Gambar 3 Uji Heteroskedastisitas}

Gambar 3 di atas menunjukkan data berada diatas atau dibawah dari 0 dan data lebih cenderung menyebar dan tidak membentuk pola-pola tertentu, maka dapat disimpulkan pada analisis ini tidak terjadi 
Pengaruh Kompetensi Sumber Daya Manusia, Partisipasi Penyusunan Anggaran, Pemanfaatan Teknologi Informasi dan Sistem Pengendalian Internal Terhadap Kualitas Laporan Keuangan Pemda Kerinci (Destipa Imelia, Sri Rahayu dan Wiralestari)

heteroskedasititas.artinya asumsi heterokedasitas terpenuhi.

\subsection{Koefisien Determinasi $\left(\mathbf{R}^{2}\right)$}

Untuk mengetahui seberapa besar Pengaruh kompetensi SDM, partisipasi penyusunan anggaran, pemanfaatan teknologi informasi dan sistempengendalian internal terhadap kualitas laporan keuangan Pemda. Kerinci secara simultan.Untuk mengetahui hasil analisis besarnya pengaruh, maka dapat dijelaskan pada tabel 9:

Tabel 9. Koefisien Determinasi

\begin{tabular}{|c|c|c|c|c|}
\hline \multicolumn{5}{|c|}{ Model Summary } \\
\hline Model & $\mathrm{R}$ & R Square & $\begin{array}{r}\text { Adjusted R } \\
\text { Square }\end{array}$ & $\begin{array}{r}\text { Std. Error } \\
\text { of the } \\
\text { Estimate }\end{array}$ \\
\hline 1 &, $549^{a}$ & ,302 & 270 & 3,294 \\
\hline
\end{tabular}

a. Predictors: (Constant), Kompetensi Sdm, Partisipasi Penyusunan Anggaran, Penggunaan Ti, Sistem Pengendalian Internal,

Sumber : Output SPSS (2020)

Besar pengaruh variabel kompetensi SDM, partisipasi penyusunan anggaran, pemanfaatan teknologi informasi dan sistem pengendalian internal terhadap kualitas laporan keuangan Pemda Kerinci ditunjukkan oleh nilai Ajusted R square sebesar 0,270 .artinya, 27.0\% kualitas laporan keuangan pemda Kerinci dipengaruhi oleh kompetensi SDM, partisipasi penyusunan anggaran, pemanfaatan teknologi informasi dan sistem pengendalian internal. Sisa $73 \%$ dipengaruhi oleh variabel selain kompetensi SDM, partisipasi penyusunan anggaran, pemanfaatan teknologi informasi dan sistem pengendalian internal atau faktor - faktor lain di luar model penelitian ini seperti variabel good governance (Zeyn 2011), dan variabel pemahaman standar akuntansi pemerintah (Abdullah 2017).

\subsection{Uji Hipotesis}

\subsubsection{Uji F}

Untuk menguji signifikan pengaruh kompetensi SDM, partisipasi penyusunan anggaran, pemanfaatan teknologi informasi dan systempengendalian internal terhadap kualitas laporan keuanganPemdaKerincisecara simultan. Dengan perhitungan pada didapatkan $\mathrm{F}_{\text {tabel }}$ 2,67. Dapat dianalisis uji F, sebagai berikut:

Tabel 10 ANOVA ${ }^{a}$

\begin{tabular}{|c|c|c|c|c|c|}
\hline Model & $\begin{array}{l}\text { Sum of } \\
\text { Squares }\end{array}$ & Df & $\begin{array}{l}\text { Mean } \\
\text { Square }\end{array}$ & $F$ & Sig. \\
\hline $\begin{array}{l}1 \text { Regressi } \\
\text { on }\end{array}$ & 412,901 & 4 & 103,225 & 9,513 &, $000^{\mathrm{b}}$ \\
\hline Residual & 954,906 & 88 & 10,851 & & \\
\hline Total & 1367,806 & 92 & & & \\
\hline
\end{tabular}

a. Dependent Variable: Kualitas Laporan Keuangan Pemerintah Daerah (Y) b. Predictors: (Constant), Pengendalian Internal (X4), Sdm (X1), Partisipasi Penyusunan Anggaran (X2), Pemanfaatan Teknologi Informasi (X3)

Sumber : output SPSS

Nilai F sebesar 9.513 lebih besar dari 2,67 dan tingkat signifikan 0,000 lebih kecil dari 0,05 maka dapat dikatakan $\mathrm{H}_{0}$ ditolak dan $\mathrm{H} 1$ diterima artinya Terdapat pengaruh secara simultan atau secara bersamasama variabel kompetensi SDM (X1), partisipasi penyusunan anggaran (X2), pemanfaatan teknologi informasi (X3) dan system pengendalian internal(X4) berpengaruh signifikan terhadap kualitas laporan keuangan Pemda Kerinci (Y), dan dapat disimpulkan $\mathrm{H} 1$ diterima.

\subsubsection{Uji t}

Untuk menguji signifikan pengaruh variabel kompetensi SDM, partisipasi penyusunan anggaran, pemanfaatan teknologi informasi dan system pengendalian internal terhadap kualitas laporan keuangan Pemda. Kerinci secara parsial mengunakan uji t. Dapat dianalisis uji t, sebagai berikut:

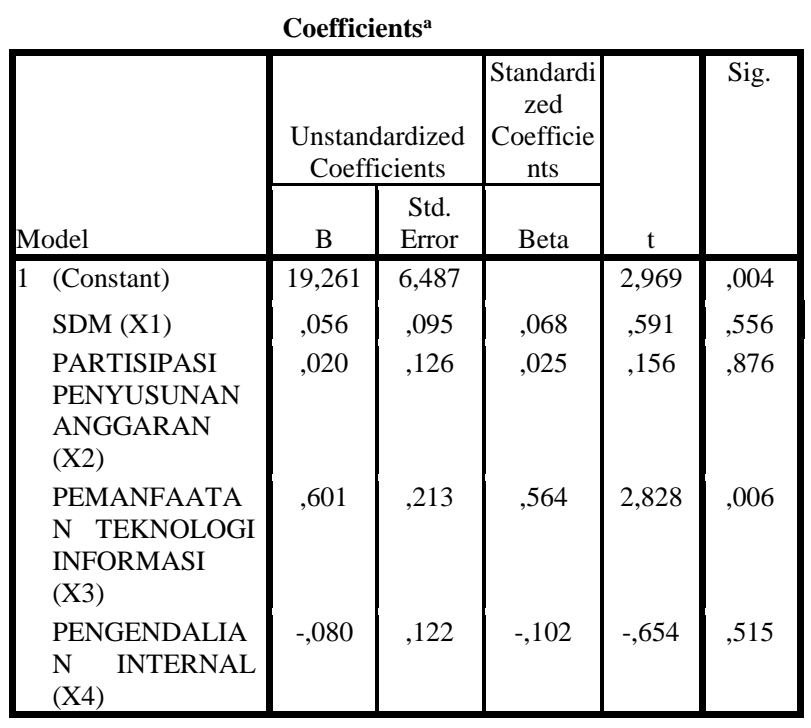

Sumber: output SPSS 22

\section{Tabel 11. Uji Parsial}

Dari tabel 11 di atas dapat digambarkan persamaan regresi sebagai berikut:

$$
\begin{aligned}
& \mathrm{Y}=\alpha+\beta_{1} X_{1}+\beta_{2} X_{2}+\beta_{3} X_{3}+\beta_{4} X_{4+} \mathrm{e} \\
& \mathrm{Y}=19,261+0,056 X_{1}+0,020 X_{2}+0,601 X_{3}+(-
\end{aligned}
$$
) $0.080 X_{4}$

Dengan penjelasan dari persamaan di atas adalah:

1. Nilai dari $\alpha=19,261$ artinya jika dianggap tidak ada nilai kompetensi SDM, Partisipasi penyususnan anggaran, pemanfaatan teknologi informasi, dan sistem pengendalian internal atau sama dengan nol, maka nilai kualitas laporan keuangan Pemda Kerinci adalah sebesar 19,261.

2. Koefisien regresi variabel kompetensi SDM sebesar 0,056 dengan arti penambahan satu satuan kompetensi SDM akan menaikan kualitas laporan keuangan sebesar 0,056 dengan asumsi variabel lain 
tetap. Selanjutnya nilai T 0,591 lebih kecil dari 1,66 dan nilai sign. 0,556 Lebih besar dari 0,05maka $\mathrm{H} \alpha$ ditolak sehingga variabel kompetensi SDM tidak berpengaruh signifikan terhadap kualitas laporan keuangan pemda kerinci dapat disimpulkan $\mathrm{H} 2$ ditolak dan Ho diterima.

3. Koefisien regresi variabel partisipasi penyusunan anggaran sebesar 0,020 dengan arti penambahan satu satuan partisipasi penyusunan anggaran akan menaikan kualitas laporan keuangan sebesar 0,020 dengan asumsi variabel lain tetap. Selanjutnya nilai t 0,156 lebih kecil dari 1,66 dan nilai sign. 0,876 Lebih besar dari 0,05 maka $\mathrm{H} \alpha$ ditolak sehingga variabel partisipasi penyusunan anggaran tidak berpengaruh signifikan terhadap kualitas laporan keuangan pemda kerinci dapat disimpulkan H3 ditolak dan Ho diterima.

4. Koefisien regresi variabel penggunaan teknologi informasi sebesar0,601 dengan arti penambahan satu satuan penggunaan teknologi informasi akan menaikan kualitas laporan keuangan sebesar 0,601 dengan asumsi variabel lain tetap. Selanjutnya nilai t 2,828 lebih besar dari 1,66 dan nilai sign. 0,006 lebih kecil dari 0,05 maka $\mathrm{H} \alpha$ diterima sehingga variabel penggunaan teknologi informasi berpengaruh signifikan terhadap kualitas laporan keuangan pemda kerinci dapat disimpulkan $\mathrm{H} 4$ diterima dan Ho ditolak.

5. Koefisien regresi variabel system pengendalian internal sebesar -0,080 dengan arti penambahan satu satuan system pengendalian internal akan menaikan kualitas laporan keuangan sebesar - 0,080 dengan asumsi variabel lain tetap. Selanjutnya nilai t -0.654 lebih kecil dari 1,66 dan nilai sign. 0,515 lebih besar dari 0,05 maka $\mathrm{H} \alpha$ ditolak sehingga variabel system pengendalian internal tidak berpengaruh signifikan terhadap kualitas laporan keuangan pemda kerinci dapat disimpulkan H5 ditolak dan Ho diterima.

\subsection{Pembahasan}

\subsubsection{Pengaruh Kompetensi SDM (X1) terhadap Kualitas Laporan Keuangan (Y)}

Soemardi (2010) menyebutkan Kompetensi dapat diartikan sebagai cerminan dari kemampuan atau keahlian seseorang pada suatu bidang tertentu seperti kemampuan prestasi, keahlian komunikasi verbal, pengetahuan teknis, kemampuan mengelola tekanan pekerjaan dan kemampuan membuat perencanaan dan keputusan.Menurut Nawawi (2005: 37) sumber daya manusia adalah semua orang yang terlibat dalam suatu pekerjaan di dalam sebuah lembaga/organisasi, dimana orang tersebut berfungsi sebagai aset yang dapat dihitung jumlahnya. Jadi, Kompetensi Sumber Daya Manusia berkaitan dengan pengetahuan, keterampilan, kemampuan atau keahlian dan sikap individu di dalam sebuah organisasi dalam mencapai tujuannya secara efektif dan efisien.

Hasil dari pengukuran kompetensi SDM pada OPD di Pemda Kerinci, rata-rata SDM di Pemda Kerinci memiliki kompetensi di bidang keuangan berada pada kategori sedang. Berdasarkan hasil uji hipotesis tidak menunjukkan adanya pengaruh yang signifikan antara Kompetensi SDM dengan kualitas laporan keuangan. Menurut penelitian Nurlaila, dkk (2016) penyebab tidak berpengaruhnya kompetensi SDM terhadap kualitas laporan keuangan suatu daerah yang telah memperoleh predikat WTP ialah disebabkan oleh sub-bagian akuntansi atau keuangan SKPD pada tahun berikutnya memiliki kompetensi sumber daya yang kurang memadai dari segi kuantitas dan kualitas dalam pembuatan laporan keuangan. Ada beberapa pegawai yang memang Sarjana Ekonomi akan tetapi bukan dari latar belakang bidang akuntan, sehingga dalam penyusunan laporan keuangan tidak sesuai dengan disiplin ilmu akuntansi.

Hal ini berarti bahwa hasil penelitian ini tidak sesuai dengan hipotesis yang penulis kemukakan sebelum dilakukannya penelitian. Meski diketahui bahwa nilai dari jawaban responden terhadap kompetensi SDM dikategorikan sedang tetapi hipotesis kedua dari penelitian ini ditolak, dimana kompetensi SDM tidak memiliki pengaruh yang signifikan terhadap kualitas laporan keuangan daerah. Berdasarkan hasil penelitian ini dapat menggambarkan bahwa responden pada OPD Pemda Kerinci belum sepenuhnya menerapkan kompetensi SDM di bidang akuntansi dalam membuat laporan keuangan.

Penelitian ini sejalan dengan penelitian oleh Hoesada, dkk (2010) dalam penelitiannya menyebutkan terkait dengan kompetensi SDM, bahwa kompetensi SDM tidak mempengaruhi kualitas laporan keuangan.Hoesada berasumsi bahwa hal ini mungkin disebabkan oleh perbedaan di wilayah sampel oleh penelitian sebelumnya dan kemungkinan dapat disebabkan oleh orang-orang yang menanggapi kebenaran dan tidak menurut data yang dikumpulkan tidak berhasil membuktikan pengaruh variabel $X$ ke variabel Y.Pada tahun 2020 Hoesada dan Ratmi dan kembali melakukan penelitian.Hasil penelitian ini menetapkan Sumber Daya Manusia tidak mempengaruhi Kualitas Laporan Keuangan daerah.

Menurut Lasmara dan Rahayu (2016) faktor yang paling dominan yaitu kompetensi sumber daya manusia hal ini di sebabkan bahwa untuk penyusunan laporan keuangan dibutuhkan sumber daya manusia yang mengerti tata cara pengelolaan keuangan.Kualitas Sumber daya manusia yang baik mampu memberikan kontribusi yang optimal sehingga tujuan organisasi tercapai. SDM yang kompeten tersebut akan mampu memahami logika akuntansi dengan baik. Kegagalan SDM pemerintah daerah dalam memahami dan menerapkan logika akuntansi akan berdampak pada kekeliruan laporan keuangan yang dibuat dan ketidaksesuaian laporan dengan standar yang ditetapkan pemerintah.

\subsubsection{Pengaruh Partisipasi Penyusunan Anggaran(X2) terhadap Kualitas Laporan Keuangan (Y)}

Partisipasi penyusunan anggaran merupakan kegiatan individu sebagai SDM mampu terlibat serta memiliki pengaruh dan mampu memberikan dampak 
dalam penentuan anggaran (Brownell,1982). Jadi, partisipasi penyusunan anggaran adalah keterlibatan pihak-pihak secara langsung dalam proses pengambilan kebijakan penyusunan anggaran. Menurut Siegel dan Marconi (1989) menyebutkan bahwa partisipasi sebagai cara untuk menyelaraskan antara tanggung jawab tugas dengan tanggung jawab terhadap tujuan organisasi.

Hasil dari pengukuran Partisipasi Penyusunan Anggaran pada OPD di Pemda Kerinci, diperoleh ratarata Partisipasi Penyusunan Anggaran di Pemda Kerinci berada pada kategori sedang. Berdasarkan hasil uji hipotesis tidak menunjukkan adanya pengaruh yang signifikan antara Partisipasi Penyusunan Anggaran terhadap kualitas laporan keuangan. Menurut penelitian yang dilakukan oleh Frucot dan Shearon (1991) dan Indriantoro (2000) menemukan bahwa penyebab tidak berpengaruhnya partisipasi dalam penyusunan anggaran dalam peningkatan kinerja manajerial yang berdampak pada hasil laporan keuangan ialah disebabkan oleh dimensi budaya organisasional. Penelitian oleh Mustikawati (1999) partisipasi dalam penyusunan anggaran dipengaruhi oleh budaya paternalistik. Pada budaya paternalistik Proses penganggaran dilakukan dengan metode top-down, yakni dalam penyusunan anggaran, pimpinan menetapkan anggaran bagi pegawai sehingga pelaksana anggaran hanya melakukan apa saja yang telah disusun. Menurut Hapsari (2010:33) pendekatan top-down ini jarang berhasil karena mengarah kepada kurangnya komitmen dari sisi pembuat anggaran dan hal ini membahayakan keberhasilan rencana anggaran hingga berdampak pada penyusunan laporan keuangan.

Menurut Sardjito dan Bambang Muthaher (2007) menurunnya komitmen organisasi dapat berakibat pada terjadinya kecenderungan untuk menurunnya kinerja aparat baik kabag/kasubag dalam berpartisipasi menyusun anggaran.Pada penelitian ini, peneliti juga menemukan kendala partisipasi penyusunan anggaran pada aspek Komitmen.Berdasarkan jawaban responden, keterlibatan pegawai dalam penyusunan anggaran tentunya sebagai wujud komitmen diri terhadap tugas dan tanggung jawab instansi. Ketidakhadiran pegawai dalam kegiatan penyusunan anggaran bukan berarti berkurangnya loyalitas dan komitmen pegawai, akan tetapi ada tugas lain yang bersamaan pentingnya sehingga pegawai tidak dapat terlibat dalam kegiatan penyusunan anggaran, sehingga partisipasi penyusunan kurang efektif bagi beberapa pegawai.

Berdasarkan hasil penelitian ini pada pengukuran pengaruh tingkat partisipasi penyusunan anggaran terhadap laporan keuangan tidak menunjukkan pengaruh yang signifikan. Hal ini sejalan dengan penelitian Pundarika (2019), Hasil analisis menunjukkan bahwa partisipasi penyusunan anggaran memiliki efek negative pada senjangan anggaran yang berdampak pada kualitas laporan keuangan. Hasil penelitian ini bertolak belakang dengan hasil penelitian oleh Pratiwi (2019), menyebutkan bahwa tujuan partisipasi penggunaan anggaran memiliki efek positif pada senjangan anggaran. Pengaruh tujuan partisipasi penggunaan anggaran pada senjangan anggaran juga dimediasi secara positif oleh partisipasi anggaran dan penekanan anggaran, sehingga laporan keuangan menjadi akurat.

\subsubsection{Pengaruh Pemanfaatan Teknologi Informasi} (X3) terhadap Kualitas Laporan Keuangn (Y)

Pemanfaatan teknologi Informasi merupakan perangkat pendukung kegiatan untuk menghasilkan Kualitas laporan Keuangan sesuai dengan PP 71 tahun 2010.Manfaat yang yang ditawarkan dalam pemanfaatan teknologi informasi adalah kecepatan dalam pemrosesan informasi. Oleh karena itu pemanfaatan teknologi informasi akan sangat membantu mempercepat proses pengolahan data transaksi dan penyajian laporan keuangan (Anggraeni, 2014).

Berdasarkan hasil jawabankuesioner dari 93 responden terhadap pertanyaan tentang Pemanfaatan Teknologi Informasi yang terbagi atas tiga indikator, yaitu intensitas pemanfaatan, frekuensi pemanfaatan, dan jumlah aplikasi atau perangkat lunak yang digunakan. Hasil yang diperoleh diketahui bahwa ratarata OPD Pemda Kerinci dapat memanfaatkan teknologi informasi dengan baik. Penggunaan teknologi informasi yang digunakan sudah sesuai dengan standar, sehingga memberikan pengaruh yang baik terhadap kualitas laporan keuangan.

Temuan hasil penelitian ini berdasarkan uji statistik terdapat pengaruh positif yang signifikan antara pemanfaatan teknologi informasi dengan kualitas laporan keuangan.Penelitian ini menunjukkan bahwa sub bagian keuangan telah melakukanpengolahan data transaksi keuangan dengan menggunakan software yang sesuai dengan perundang-undangan, laporan yang dihasilkan berasal dari sistem informasi yang terintegrasi. Penelitian ini menunjukkan bahwa masingmasing OPD Pemda Kerinci menganggap bahwa pemanfaatan teknologi informasi ada kaitannya terhadap kualitas laporan keuangan pemerintah daerah. Pemanfaatan teknologi informasi akan sangat membantu mempercepat proses pengolahan data transaksi dan penyajian laporan keuanganpemerintah daerah. Temuan ini mendukung literatur-literatur yang berkaitan dengan manfaat dari suatu teknologi informasi.

Hal ini sesuai dengan hasil penelitian oleh Mardinan dkk (2018), yang menyebutkan bahwa penggunaan teknologi informasi dalam penyusunan dan penyajian laporan keuangan juga mempengaruhi keandalan data dan informasi yang disajikan dalam laporan keuangan, agar setiap transaksi dapat lebih mudah dilacak dan diverifikasi kebenarannya melalui aplikasi yang digunakan dalam penyusunan laporan keuangan.

Berdasarkan penelitian yang dilakukan oleh Johnston dan Zhang (2018), menjelaskan pengaruh antara penggunaan Teknologi Informasi terhadap kualitas laporan keuangan, yang mana Teknologi informasi (TI) dapat dimanfaatkan untuk meningkatkan 
efisiensi produksi laporan keuangan dan efisiensi audit laporan-laporan ini. Hasil ini konsisten dengan argumen bahwa berinvestasi di TI mengurangi keterlambatan pelaporan dengan mengotomatisasi dan menyederhanakan proses pelaporan dan penutupan keuangan.

Jadi, jika penggunaan teknologi informasi dijalankan secara maksimal dan teknologi informasi diterapkan dengan baik sesuai perkembangan zaman/update maka dapat memberikan kualitas informasi keuangan,serta pemanfaatan teknologi informasi akan sangat membantu mempercepat proses pengolahan data transaksi dan penyajian laporan keuangan.

\subsubsection{Pengaruh Sistem Pengendalian Internal terhadap Kualitas Laporan Keuangan}

Sistem Pengendalian Internal merupakan suatu proses yang dijalankan oleh eksekutif yang didesain untuk memberikan keyakinan yang memadai mengenai pencapaian keandalan laporan keuangan, kepatuhan terhadap hukum dan peraturan yang berlaku, serta efektivitas dan efisiensi operasi. Menurut Peraturan Pemerintah Nomor 60 Tahun 2008 tentang Sistem Pengendalian Internal Pemerintah menyatakan bahwa: Sistem Pengendalian Internal adalah proses yang integral pada tindakan dan kegiatan yang dilakukan secara terus menerus oleh pimpinan dan seluruh pegawai untuk memberikan keyakinan memadai atas tercapainya tujuan organisasi melalui kegiatan yang efektif dan efisien, keandalan pelaporan keuangan, pengamanan aset negara, dan ketaatan terhadap peraturan perundang-undangan.

Berdasarkan hasil analisis jawaban responden, diketahui secara keseluruhan Sistem Pengendalian Internal Pemda Kerinci rata-rata berada pada kategori sedang.Hasil pengukuran statistik hipotesis H5 ditolak, yakni tidak terdapat pengaruh yang signifikan antara Sistem Pengendalian Internal terhadap kualitas laporan keuangan.

Menurut Nurlaila, $\operatorname{dkk}(2016)$ penyebab tidak berpengaruhnya Sistem Pengendalian Internal terhadap kualitas laporan keuangan disebabkan sub bagian akuntansi atau keuangan di SKPD belum sepenuhnya menyelenggarakan sistem akuntansi yang meliputi prosedur akuntansi penerimaan kas, pengeluaran kas, aset dan selain kas. Selain itu, transaksi yang ada dapat dilakukan tanpa adanya otorisasi dari pihak berwenang, setiap transaksi yang terjadi kurang didukung dengan bukti yang valid dan sah, dan tidak adanya pemisahan tugas dalam rangka pelasanaan APBD.

Menurut Septriani dan Frans Papilaya (2016) penyebab tidak berpengaruhnya sistem pengendalian internal terhadap kualitas laporan keuangan bisa dikarenakan oleh system pengendalian internal yang sudah berjalan dengan baik, namun tidak sejalan dengan kebijakan yang diambil oleh pimpinan tentu tidak akan memberikan pengaruh pada kualitas laporan keuangan yang dihasilkan. Akan tetapi hal diatas tidak terjadi pada Pemda.Kerinci yang telah memperoleh predikat WTP.Peneliti tidak menemukan kelemahan atau kesalahan yang fatal dalam penerapan pengendalian internal.

Menurut peneliti hal ini terjadi mungkin sebagai dampak dari kurangnya SDM di bidang akuntansi, sehingga terbatasnya jumlah Aparat dalam Pemeriksaan Intern Pemerintah. Menurut Akhmad Syarifudin (2014) jika suatu OPD kekurangan jumlah Aparat Pemeriksa Intern Pemerintah (APIP) maka akan menyebabkan peran audit intern kurang optimal dalam membantu manajemen untuk memastikan bahwa seluruh kegiatan telah dilakukan sesuai dengan aturan secara efisien dan efektif dalam mencapai tujuan yang telah ditetapkan. Sehingga kurangnya pelaksanaan penilaian dan evaluasi terhadapkualitas pengendalian internal di suatu daerah. Hal ini penting untuk ditingkatkan sebagai langkah awal dalam pengendalian resiko pada permasalahan kerugian atau pada perencanaan keuangan pada masa yang akan dating. Hasil penelitian ini bertolakbelakang dengan hasil penelitian yang disampaikan oleh Afiah, dkk (2015), Kasim (2015), Herawati (2014), dan Sudarianti (2015)

Tujuan sistem pengendalian internal yaitu: menyajikan data yang dapat dipercaya, meningkatkan efisiensi operasional, mendorong pelaksanaan kebijaksanaan yang ada, melindungi harta milik negara, memeriksa kecermatan dan keandalan data akuntansi, meningkatkan efisiensi usaha, mendorong ditaatinya kebijakan yang telah digariskan, dan meningkatkan kualitas laporan keuangan. Instansi pemerintah wajib menerapkan setiap unsur dari Sistem Pengendalian Internal untuk mencapai visi dan misi serta pertanggungjawaban kegiatan instansi pemerintah. Kegiatan instansi pemerintah juga perlu adanya pemantauan secara terus-menerus dalam rangka memastikan bahwa Sistem Pengendalian Internal sudah dirancang dan diimplementasikan dengan baik. Pemantauan tersebut dilakukan untuk mengidentifikasi dan mengatasi risiko seperti pemborosan, penggelapan, dan penyalahgunaan.Dengan demikian, itu perlu adanya pengendalian internal untuk mengatur dan mengarahkan aktivitas suatu perusahaan/instansi.

4.5.5. Pengaruh Kompetensi SDM, Partisipasi Penyusunan Anggaran, Penggunaan TI, dan Pengendalian Internal terhadap Kualitas Laporan Keuangan.

Kualitas Laporan Keuangan merupakan ukuranukuran normatif dari laporan keuangan yang perlu dicapai dalam informasi akuntansi agar tercapai tujuannya dan memenuhi kualitas yang dikehendaki, yang memenuhi karakterisktik sesuai dengan PP 71 tahun 2010.

Hasil analisis yang di kumpulkan menggunakan angket di peroleh secara keseluruhan kualitas laporan keuangan di Pemda Kerinci sudah baik dan sesuai standar aturan yang berlaku.Hal ini karena ditunjang oleh faktor Kompetensi sumber daya manusia, penggunaan teknologi informasi dan pengendalian 
internal dan partisipasi penyusunan anggaran secara bersama-sama berdasarkan hasil uji simultan. Hasil analisis diperoleh terdapat pengaruh yang signifikan antara Kompetensi sumber daya manusia, penggunaan teknologi informasi dan pengendalian internal dan partisipasi penyusunan anggaran terhadap kualiatas laporan keuangan. Namun pengaruhnya tidak begitu kuat, hal ini dikarenakan ada pengaruh faktor lain diluar dari penelitian ini lebih kuat dibandingkan dengan pengaruh faktor Kompetensi sumber daya manusia, penggunaan teknologi informasi dan pengendalian internal dan partisipasi penyusunan anggaran.

Ada banyak penelitian yang mengkaji faktor penentu kualitas laporan keuangan.Terdapat beberapa penelitian terdahulu yang menunjukkan ketidak konsistenan pengaruh antara kompetensi SDM, pemanfaatan TI, pengendalian internal dan partisipasi penyusunan anggaran terhadap kualitas laporan keuangan.Pada hasil penelitian ini menunjukkan adanya faktor pengaruh yang signifikan. Hal ini sejalan dengan hasil penelitian Puspitawati (2016) bahwa Kompetensi Sumber Daya Manusia (SDM), dan Penerapan Sistem Pengendalian Intern Pemerintah (SPIP) secara bersamasama berpengaruh positif terhadap kualitas LKPD di Provinsi Lampung. Menurut Arfiyanti (2011) diantara faktor penentu kualitas laporan keuangan adalah Kompetensi sumber daya manusia, penggunaan teknologi informasi dan pengendalian internal yang secara bersama-sama akan meningkatkan kualitas laporan keuangan. Jannah (2018) menyebutkan faktor tambahan penentu kualitas laporan keuangan ialah dipengaruhi oleh partisipasi penyusunan anggaran.

Selanjutnya penelitian oleh Ratmi dan Jan Hoesada (2020) bahwa Aplikasi Pemanfaatan Teknologi Informasi berpengaruh Kualitas Laporan Keuangan, Penerapan Teknologi Informasi salatu faktor yang mendukung hal manajemen keuangan unit kerja daerah untuk menghasilkan laporan keuangan yang berkaulitas sesuai dengan standar yang ditetapkan oleh Dewan Audit Republik dari Indonesia. Laporan keuangan disusun untuk memenuhi kebutuhan para pemakai. Para pemakai tersebut menggunakannya untuk meramalkan, membandingkan dan menilai dampak keuangan yang timbul dari keputusan yang diambilnya.Selain itu laporan keuangan juga untuk menilai kemampuan sebuah entitas dan bertujuan sebagai pertimbangan dalam pengambilan keputusan.Kualitas laporan keuangan merupakansejauh mana laporan keuangan yang disajikan menunjukkan informasi yang benar dan jujur.Laporan keuangan yang berkualitas berguna sebagai dasar pengambilan keputusan ekonomi bagi pihak yang berkepentingan.

\section{SIMPULAN DAN SARAN}

\subsection{Simpulan}

1. Secara Simultan Kompetensi Sumber Daya Manusia, Partisipasi penyusunan anggaran, pemanfaatan teknologi informasi dan sistem pengendalian intern pemerintah berpengaruh signifikan rendah terhadap kualitas laporan keuangan.

2. Kompetensi Sumber Daya Manusia tidak berpengaruh terhadap kualitas laporan keuangan disebabkan karena pemda .

3. Partisipasi penyusunan anggaran tidak berpengaruh terhadap kualitas laporan keuangan.

4. Pemanfaatan teknologi informasi berpengaruh positif terhadap kualitas laporan keuangan.

5. Sistem pengendalian intern tidak berpengaruh terhadap kualitas laporan keuangan daerah.

\subsection{Saran dan Keterbatasan} adalah:

Saran yang dapat dirumuskan dalam penelitian ini

1. Secara bersama-sama Kompetensi SDM, Partisipasi penyusunan anggaran, pemanfaatan teknologi informasi dan sistem pengendalian intern pemerintah berpengaruh signifikan terhadap kualitas laporan keuangan dengan pengaruh yang rendah. Hal ini berarti jika suatu OPD didukung oleh faktor kompetensi sumber daya manusia partisipasi penyusunan anggaran, pemanfaatan teknologi informasi dan sistem pengendalian internalyang diterapkan secara bersama-sama maka akan bisa mewujudkan laporan keuangan yang berkulitas. Laporan keuangan yang berkualitas dapat digunakan untuk pengambilan keputusan. Hal ini sejalan dengan penelitian Arfiyanti (2011), Jannah (2018), Hoesada (2020), dan Puspitawati (2016). Untuk mempertahankan predikat WTP yang telah diperoleh oleh Pemda Kerinci, sebaiknya OPD lebih memperhatikan penerapan Partisipasi Penyusunan Anggaran dan Sistem Pengendalian Intern dengan melakukan peningkatan kualitas sumber daya manusia yang benar-benar memiliki kompetensi khususnya dibidang Akuntansi dan integritas yang tinggi, sehingga paham terhadap standar dan aturan yang sudah ditetapkan serta faktor-faktor penguat lainnya diluar dari penelitian ini yang harus diperhatikan untuk mendukung kualitas laporan keuangan Pemda Kerinci.

2. Kompetensi Sumber Daya Manusia tidak berpengaruh terhadap kualitas laporan keuangan sehingga Perlu adanya peningkatan nilai sumber daya manusia yang memiliki latar belakang pendidikan Akuntansi. Nurlaila, dkk (2016) penyebab tidak berpengaruhnya kompetensi SDM terhadap kualitas laporan keuangan suatu daerah yang telah memperoleh predikat WTP disebabkan Sumber Daya Manusia beberapa pegawai yang memang Sarjana Ekonomi akan tetapi bukan dari latar belakang bidang akuntan, sehingga dalam penyusunan laporan keuangan tidak sesuai dengan disiplin ilmu akuntansi.

3. Perlunya Peningkatan Parstipasi Penyusunan Anggaran pada Pemda Kerinci dengan menambahkan Pelatihan tentang Keuangan sehingga bisa meningkatkan Partisipasi dalam 
Penyusunan Anggaran. Partisipasi Penyusunan Anggaran tidak berpengaruh terhadap kualitas Laporan Keuangan dikarenakan tugas lain yang bersamaan pentingnya sehingga pegawai tidak dapat terlibat dalam kegiatan penyusunan anggaran, sehingga partisipasi penyusunan kurang efektif bagi beberapa pegawai. Hal ini sejalan dengan penelitian Sardjito dan Bambang Muthaher (2007) menurunnya komitmen organisasi dapat berakibat pada terjadinya kecenderungan untuk menurunnya kinerja aparat baik kabag/kasubag dalam berpartisipasi menyusun anggaran.

4. Pemanfaatan teknologi informasi berpengaruh positif terhadap kualitas laporan keuangan. Penelitian ini menunjukkan bahwa sub bagian keuangan telah melakukan pengolahan data transaksi keuangan dengan menggunakan software yang sesuai dengan perundang-undangan, laporan yang dihasilkan berasal dari sistem informasi yang terintegrasi. Penelitian ini menunjukkan bahwa masing-masing OPD Pemda Kerinci menganggap bahwa pemanfaatan teknologi informasi ada kaitannya terhadap kualitas laporan keuangan pemerintah daerah. Hal ini sejalan dengan penelitian Johnston dan Zhang (2018) dan Mardinan dkk (2018).

5. Sistem pengendalian intern tidak berpengaruh terhadap kualitas laporan keuangan daerah. Akibat Terjadinya Pergeseran Realisasi Anggaran dan Perubahan Neraca pada bagian Aset pada Pemda Kerinciyang terjadi di lingkup kerja Pemda Kerinci sedini mungkin bisa terdeteksi sehingga hal demikian bisa diminimalisirkan untuk terjadi. Hal ini terjadi sebagai dampak dari kurangnya SDM di bidang akuntansi, sehingga terbatasnya jumlah Aparat dalam Pemeriksaan Intern Pemerintah. Sesuai dengan yang dikemukakan Akhmad Syarifudin (2014) jika suatu OPD kekurangan jumlah Aparat Pemeriksa Intern Pemerintah (APIP) maka akan menyebabkan peran audit intern kurang optimal dalam membantu manajemen untuk memastikan bahwa seluruh kegiatan telah dilakukan sesuai dengan aturan secara efisien dan efektif dalam mencapai tujuan yang telah ditetapkan. Sehingga kurangnya pelaksanaan penilaian dan evaluasi terhadapkualitas pengendalian internal di suatu daerah.

6. Penelitian selanjutnya dapat dilengkapi metode survei dengan wawancara untuk meningkatkan sikap kepedulian dan keseriusan responden dalam menjawab semua pertanyaan yang diajukan dan mengurangi subjektivitas dari responden yang bisa mengakibatkan hasil penelitian ini rentan terhadap biasnya jawaban responden.

7. Peneliti selanjutnya disarankan untuk mengembangkan variabel penelitian, tidak hanya pada variabel dependen dan independen, tetapi juga dapat menambahkan variabel pemoderasi atau intervening dan obyek penelitian tidak hanya pada lingkup OPD
Pemda Kerinci, akan tetapi mencakup semua OPD yang ada di Provinsi Jambi baik yang telah mendapat predikat WTP ataupun yang belum.

Berdasarkan hasil pembahsan dalam penelitia ini, maka dapat disampaikan beberapa keterbatasan penelitian, yaitu sebagai berikut:

1. Penulis hanya memasukkan variabel dependen dan variabel independen tanpa adanya variabel moderating yang memoderasi variabel $\mathrm{X}$ ke variabel Y dalam mempengaruhi laporan keuangan di PemdaKerinci.

2. Ruang lingkup penelitian ini hanya dilakukan pada satuan kerja pemerintah daerah diwilayah Kerinci, sehingga generalisasi hasil temuan dan rekomendasi penelitian ini kurang dapat dilakukan bagi daerah diluar wilayah Kerinci.

\section{DAFTAR REFERENSI}

Bastian, Indra. (2006). Akuntansi Sektor Publik: Suatu Pengantar. Jakarta: Erlangga.

BPKP. (n.d.). BPKP. Retrieved from www.bpkp.go.id

Brownell, P., \& Morris Mc Innes. (1986). "Budgetary Participation, Motivation, and Performance”. The Accounting Review, Vol.61, No.4, October 1986 page 587-600.

Ihsanti, E. (2014).Pengaruh Kompetensi Sumber Daya Manusia dan Penerapan Sistem Akuntansi Keuangan Daerah terhadap Kualitas Laporan Keuangan Daerah (Studi Empiris Pada SKPD Kabupaten Lima Puluh Kota).Artikel. Padang: Universitas Negeri Padang.

Iskandar Muda, Deni Yuwilia Wardani dkk (2005). JurnalThe influence of human resources competency And the use of information technology on the Quality of local government financial report With regional accounting system as an Intervening. Vol.95. No 20

Jensen, Michael C; Meckling, W. H. (1937). Theory of the firm: managerial behavior, agency costs and ownership structure. Strategic Management Journal, 13(4), 223-242. https://doi.org/10.1002/mde.1218

Nawawi, Hadari. (2005). Perencanaan SDM untuk Organisasi Profit yang Kompetitif. Yogyakarta: Gajah Mada University Press.

Nunuy Nur Afiah, Dien Noviany Rahmatika (2014).Factors influencing the quality of financial reporting and its Implications on good government governance (Research on Local Government Indonesia).Vol. 5, Issue 1 (Dec.)

Peraturan Pemerintah Nomor 71 Tahun 2010 tentang Standar Akuntansi Pemerintahan. 
Peraturan Pemerintah Nomor 58 Tahun 2005 tentang Pengelolaan Keuangan Daerah.

Peraturan Pemerintah Nomor 60 Tahun 2008 tentang Sistem Pengendalian Internal Pemerintah.

Scott, W. R. (2015). Financial Accounting. In An introduction Macmillan (7th ed., Vol. 1). Toronto: Ontario Pearson.

Sugiyono.(2018). Statistika untuk Penelitian.Bandung: Alfabeta. (2015). Metode Penelitian Kuantitatif Kualitatif dan R\&D. Bandung: CVAlfabeta

Trisdina Mardinan, (2018). Effect of Human Resources, Leadership Style, The Use of Information Technology and Internal Control on the Quality of Financial Statements.Journal of Accounting Auditing and Business (JAAB) Vol 1 No.1

Yeyen Pratiwi. (2019). The Effect OfPurpose Of Budget Use On Budgetary Slack With Budget Participation And Budget Emphasis As Mediating Variable. International Journal Of Progressive Vol 13, No 2 